\title{
ENGLISH IDIOMS CONTAINING HUMAN-BODY PARTS AND THEIR VIETNAMESE EQUIVALENTS: A CASE STUDY OF TWO ENGLISH NOVELS AND THEIR VIETNAMESE TRANSLATION VERSIONS
}

\author{
Nguyen Thu Hanh", ${ }^{*}$, Nguyen Tien Long ${ }^{2}$ \\ 1. Department of English, Military Science Academy \\ Kim Chung, Hoai Duc, Hanoi, Vietnam \\ 2. Political Department, Naval Region 4 \\ Cam Nghia, Cam Ranh, Khanh Hoa, Vietnam \\ Received 20 November 2018 \\ Revised 11 May 2019; Accepted 31 May 2019
}

\begin{abstract}
The current paper focuses on investigating the semantic and syntactic features of idioms, including idioms containing human-body parts in the two English novels "The Godfather", "To Kill A Mockingbird" and their Vietnamese translation versions. Using comparison and contrast method, the paper attempts to point out the equivalent and non-equivalent references of humanbody-part idioms found in the two English novels and their Vietnamese translation. The research results will be useful for improving English teaching and learning, especially English idioms, as well as English-Vietnamese translation of idioms.
\end{abstract}

Keywords: idioms, equivalent, human-body parts, English-Vietnamese translation

\section{Introduction}

Idioms are an intriguing and common phenomenon in every language. They are used in everyday life and are usually employed to express ideas and concepts that cannot be compressed into one single word. Idioms always show the uniqueness of the way each nation perceives the outside world and reacts towards that world. They serve as quintessence in each language treasure; hence, studying idioms helps learners master a language in terms of not only lexicology but grammar as well. In addition, learning foreign idioms is one of the best ways to gain invaluable insights into different cultures and human psychology.

Corresponding author. Tel: 84-989150875

Email: nguyenthuhanh09@gmail.com.
Among large quantities of idioms, idioms containing human-body parts account for a major part of both Vietnamese and English. Nonetheless, due to a certain gap in linguistic and literary perspectives these human-bodypart idioms have not received enough attention from linguists in both languages. Therefore, it is of paramount importance to conduct a research entitled "English idioms containing human-body parts and their Vietnamese equivalents: a case study of two English novels and their Vietnamese translation versions". This research aims to spell out the syntactic and semantic features of English and Vietnamese idioms containing human-body parts, and then it applies translation strategies to point out the equivalence and nonequivalence between English and Vietnamese idioms containing human-body parts used in 
two selected English novels "The Godfather" (1969) and "To Kill a Mockingbird" (2015) and their Vietnamese translated versions "Bố già" (2017) and "Giết con chim nhại" (2017) respectively. As a practical part of the research, several strategies for learning and translating English idioms containing humanbody parts into Vietnamese will be suggested.

Within the scope of this study, not all linguistic issues related to idioms will be covered, and only a limited number of idioms containing human-body parts from the selected data sources are mentioned.

\section{Theoretical background}

\subsection{Overview of idioms in English}

\subsubsection{Definitions}

In his well-known book Idiom structure in English, Makkai claims that idiom is, firstly, a unit realized by at least two words; secondly, from its component parts, one cannot deduce the meaning of the idiom; thirdly, idioms manifest a high level of disinformation potential; fourthly, idioms are institutionalized; in other words, they are conventionalized expressions (1972). From the etymological perspective of Linda and Roger Flavell, idioms are "anomalies of language, mavericks of the linguistic world" (2000: 6). They point out that "the best examples of idioms are very fixed grammatically and it is impossible to guess their meanings from the sense of the words that constitute them" (2000: 6). Regarding the meaning of idioms, Fowler et al. (1976: 533) define idioms as a "peculiarity of phraseology approved by usage though having meaning not deducible from those of the separate words". In conclusion, notwithstanding the variations in viewpoints among many researchers and linguists, idioms are commonly regarded as fixed expressions whose components are well-structured and hardly separable; and their meanings cannot always be worked out by combining the literal meaning of their individual words.

\subsubsection{Classification of English idioms}

Regarding semantic cohesion, Cowie (1998) and Moon (1998) classify English idioms into three classes with the motivation degree of their meaning, namely phraseological fusions, phraseological unities and phraseological combinations. Phraseological fusions have a very low degree of motivation, i.e. they can be completely non-motivated. Due to their high idiomaticity, the meaning of the whole idiom cannot be inferred from the meaning of its constituents, e.g. "white elephant" (an expensive but useless thing). Phraseological combinations are partially motivated idioms as their meaning can usually be perceived through metaphoric or metonymic denotation e.g. "to come through something with flying colors" (to win or accomplish something exceptionally well or very successfully). Phraseological combinations are obviously motivated idioms and are typically referred to as "collocations" such as "to keep an/one's eye on someone/ something" (keep someone/ something under careful observation).

Based on structures, Arnold (1986: 172) classifies idioms according to parts of speech. This is also called syntactical classification. Thus, idioms are categorized into seven types as follows: nominal idioms such as "the last straw" (the final problem in a series of problems); verbal idioms such as "to cut corners" (to do something in the easiest, cheapest, or fastest way); adjectival idioms, e.g. "hale and hearty" (healthy and strong); adverbial idioms like "on balance" (after considering all aspects or opinions); prepositional idioms such as "with regard to" 
(as concerns; with respect to); conjunctional idioms like "on the other hand" (in a way that is different from the first thing mentioned) and interjectional idioms such as "God bless you!" (Good luck).

In terms of functions, Koonin (1970: 140) classifies idioms into four main categories: nominative idioms denoting objects, actions, qualities... such as " $a$ red letter day" (a very important day); nominative-communicative idioms as verbal word groups that can be converted into a sentence such as "to make waves" (to cause wide impact on a group or society in general); interjectional idioms functioning as exclamational phraseological units to express feelings and emotions, e.g. "get stuffed!" ("go away"); and communicative idioms being similar to proverbs and concrete sayings, appearing as full sentences, e.g. "never look a gift horse in the mouth" (if someone offers you a gift, don't question it).

\subsubsection{Typical features of English idioms}

Syntactically, structural invariability constitutes the most vital feature of idioms. Arnold (1986) and Makkai (1972) claim three commonly accepted structural restrictions of English idioms. First, it is the restriction in substitution which contributes to the syntactic uniqueness of English idioms. For example, the idiom "take with a grain of salt" means "not to take what somebody says too seriously", but "a grain of sugar" does not make any sense at all. Nevertheless, there are some cases in which some components are variable such as "to add fuel to the firel flames" (to make an argument or bad situation worse), yet such situations are not very common in English. Not allowing addition of any sub-components to the fixed structure is the second limitation to idioms. In the idiom "one's hands are tied" (one does not have the ability to act, help or intervene) no other words can be added. Thus, "one's big hands are tied" is not an idiom but a free word group. Several uncommon exceptions of this kind are "at a (single) stroke" (with a single immediate action), "to give something to someone on a (silver) platter" (to let someone get something very easily). The third kind of restriction is grammatical uniformity. Many English learners use the word "eye" in plural form in the idiom "to see eye to eye" (to agree with each other) to become "to see eyes to eyes", which is a common mistake. Again, several idioms have a noun component with either plural or singular form, e.g. "to add fuel to the flame/ flames", "to have string/ strings to your bow" (to have more than one skill or plan that you can use if you need to) but in general, idioms have a rather fixed form in terms of grammar.

Semantically, figurativeness is one of the basic features of idioms. Cowie (1998) considers the meaning of idioms the chemical mixture of meanings of all components. In fact, his remark is quite well-founded as the meaning of idioms has been transferred compared to that of their components. For example, the idiom "to cry over spilt milk" conveys the intended meaning "to express regret about something that has already happened or cannot be changed" much better than its literal equivalent because it conveys a message that its literal components cannot. When we compare "to cry over" to "to regret" and "spilt milk" to "things that already happened in the past", the idiom seems to make more sense and can be easily perceived. Another semantic feature is that the meaning of idioms can vary from positive, neutral to negative one. There exists a large quantity of idioms having positive meanings like "every cloud has a silver lining" (be optimistic, even difficult times will lead to better days), "on the ball" (when someone understands the 
situation well). Some neutral idioms are "best of both worlds" (all the advantages), "keep something at bay" (to keep something away), just a few to name. However, many other idioms contain negative contents such as "to feel a bit under the weather" (to feel slightly ill) or "to miss the boat" (to miss a chance).

2.1.4. English idioms containing humanbody parts

As previously mentioned, an idiom is generally seen as a colloquial metaphor and thanks to this metaphorical characteristic, idioms, including idioms which contain human-body parts, make languages colorful and rich, thus enabling them to effectively reflect human experiences and the ways people understand the world around them. Since human body is very familiar to human beings, idioms containing body parts are closely associated with the sensual aspects of human existence. Stoyanova (2009) claims that human-body-part expressions or somatic phrases are one of the most frequentlyencountered idiom types in English.

Based on the objects of denotation, Stoyanova (2009: 3) classifies the somatic expressions into the following groups: (a) Somonymic lexis denoting parts of the human body (hand, neck, heart) such as "from head to foot" (all over the body), or "dead from the neck up" (extremely stupid); (b) Osteonymic lexis denoting parts of the skeletal system of human organism: "skin and bones" (painfully thin), "to make no bones about something" (try not to hide one's feelings); (c) Angionymic lexis denoting parts of circulatory system of the human organism "in one's blood" (part of one's genetic makeup), "blue blood" (a member of an upper-class family); (d) Splanchnonymic lexis denoting internal organs of the human body: "at the top of one's lungs" (to shout as loudly as one can), "from the bottom of one's heart" (sincerely); (e) Sensonymic lexis denoting sense organs of the human body: "to be all ears" (to be listening eagerly and attentively), "the apple of somebody's eye" (the person who someone loves most and is very proud of); (f) General body lexis refering to body such as "in the flesh" (in person), "to press the flesh" (to shake hands with a lot of people).

The semantic features of English humanbody-part idioms are no less important. They can express human passions and feelings or traits of human character. Accordingly, Stoyanova divides human-body-part idioms into several thematic groups (2009: 6): (a) Human emotions and feelings: human-bodypart idioms can express emotions such as delight, happiness, joy as in "to carry somebody off his/her feet", love or passion such as "to win somebody's hand". On the other hand, human-body-part idioms can express strong feelings of resentment and hopelessness "to wring one's hand" or exhaustion and tiredness "to be dead on one's feet"; (b) Traits of human characters: these human-body-part idioms are based on positive and negative features of human nature. The concept of laziness can be conveyed by "to fold one's hands", cowardice can be mocked at by the expression "to get cold feet", while bravery can be admired by "to get oneself in hand". The ability to react quickly can be highlighted by "to think on one's feet". To demonstrate psychological stability, the idiom "to find one's feet" can be deployed; (c) Features of different phenomena: This group of humanbody-part idioms covers various aspects of life such as cognitive approach or personal and impersonal relationships. For example, a concept of unity and peace may be expressed by "to be at logger heads with somebody", challenge and concession can involve the expression "to gain the upper hand", attempt 
and violence can be rendered by "to fight hand in hand", for power and influence one can use "to have long hands", "or "a hidden hand". In sum, English human-body-part idioms are very rich in their meanings, from human desires and feelings or qualities of human characters.

\subsection{Overview of idioms in Vietnamese}

\subsubsection{Definitions}

From the viewpoint of Nguyễn Thiện Giáp (1996), idioms are fixed phrases with both completeness and figurativeness in meaning. Besides the intellectual content, they always contain certain attitudes like appreciation, respect, disdain or disgust. Sharing a similar definition of idiom, Hoàng Văn Hành (2004) claims that idioms are complex combinations of stable structures which are complete and figurative in meaning, commonly used in daily interactions, especially in spoken language. Mai Ngọc Chừ and his associates support the same idea that idioms are fixed phrases with complete structures and meanings which are symbolic and expressive (1997).

From the above linguists' opinions, it can be concluded that idioms are fixed terms (fixed phrases) that are relatively stable in form, used to name things, qualities, and actions. The general meanings of idioms go beyond the meanings of their equivalent expressions in terms of refinement and figurativeness.

\subsubsection{Classification of Vietnamese idioms}

According to Nguyễn Đình Hiền (2018) and Hoàng Thị Yến (2017), based on structure, Vietnamese idioms can be divided into three following types: First, symmetrical idioms are the idioms containing two symmetrical parts with an "axis" in the middle. Most Vietnamese idioms have an "even number" of components. Supposing A, B, C, D are four components of the idiom, there is a symmetry between $\mathrm{AB}$ and $\mathrm{CD}$, in which " $\mathrm{A}$ and $\mathrm{C}$ " belong to the same scope of meaning, or the same part of speech, and so do "B and D". For instance, the idiom "học truoóc quên sau" (easily forget what one has learnt) has the following structure:

$\begin{array}{llll}\text { A } & \text { B } & \text { C } & \text { D } \\ \text { Học } & \text { trước } & \text { quên } & \text { sau } \\ \text { learn } & \text { before } & \text { forget } & \text { after } \\ \text { "Easily forget what one has learnt." } & \end{array}$

In this example, "học" and "quên" are both verbs and belong to the same scope of meaning while "truoóc" and "sau" belong to another scope of meaning. If $\mathrm{A}$ and $\mathrm{C}$ are repeated, the structure will become:

$\begin{array}{lllll}\text { A } & \text { B } & \text { A } & \text { D } & \\ \text { Một } & \text { lòng } & \text { một } & \text { dạ } & \text { (stay loyal) } \\ \text { Bách } & \text { chiến } & \text { bách } & \text { thắng } & \text { (be invicible) }\end{array}$

However, a proportion of Vietnamese idioms can also contain an "odd number" of components and the symmetry between two parts is still retained. In these idioms, the verbs in the middle are "axes" of the idioms, e.g. "cá lớn nuốt cá bé" (the great fish eats the small), "mồm miệng đõ chân tay" (a long tongue is a sign of a short hand).

Second, comparative idioms (similes) are stable combinations originating from representative comparisons. Despite their derivations from comparisons, comparative idioms still retain structural distinctions and they are composed of full form: $\boldsymbol{A} \boldsymbol{n h} \boldsymbol{u} \boldsymbol{B}$ such as "den nhu muc" (to be as black as ink), "chậm nhu rùa" (to be too slow); or simplified form with comparative word: $(\boldsymbol{A})$ nhu $\boldsymbol{B}$ such as "(anh em) nhu tay với chân" (to have a close tie), "(đurợc lời) nhu cởi tấm lòng" (one feels relieved when saying his/ her restrained thoughts out loud); and simplified form without comparative word: $\boldsymbol{A}$ (nhw) B like "thẳng (nhu) ruột ngự" (to be 
straightforward), "mắt (nhu) lọn luộc" (with eyes wide open).

The third type is ordinary idioms which are neither symmetrical nor comparative, and are usually fixed phrases such as "con dao hai luỡi" (a matter always has two sides) and "múa rìu qua mắt thơ"” (never offer to teach fish to swim); or subject-verb structures such as "cò đã đến tay" (to seize an opportunity when it comes).

\subsubsection{Typical features of Vietnamese idioms}

One syntactic feature of Vietnamese idioms is their fixedness. Vietnamese idioms are a combination of fixed words with a relatively high degree of stability. As a communication tool of any community, such forms of language are created, refined and manipulated to become idioms with a high level of inflexibility. For instance, the idiom "đen nhu côt nhà cháy" (to be black as coal; very dark) is established through practical experiences and observations of people in a relatively long time. It uses the comparative word " $n h u$ " to compare the characteristic "black" of something with fixed object "côt nhà cháy", but not "côt nhà gố" or "cột nhà bếp". However, in some other cases, although the idioms have reached a high level of invariability, one can still change the whole structures or even the fixed terms a little bit. For example, the idiomatic expression "châu chấu đá $x e$ " (to throw a straw against the wind; to attempt to do something futile) has several variations such as "châu chấu đá voi" or "châu chấu đấu voi" (Nguyễn Xuân Hiếu and Trần Mộng Chu, 1960). Despite the fixed characteristic of Vietnamese idioms, a proportion of them have undergone changes in form but their general meanings have not been altered very much. The reduplication and symmetry of Vietnamese idioms are expressed in terms of phonetic harmony of constituent elements. It has an effect of creating a rhythm, therefore creating an attraction that makes it easy to read and remember as well as leaving a deep impression in the recipient's heart. Some examples are "mắt tròn mắt dẹt" (to be very surprised or scared), "khéo chân khéo tay" (to be skillful at doing something), "súc dài vai rộng" (to be strong and healthy).

Regarding semantic features, a huge quantity of Vietnamese idioms is multimeaningful, but of all these meanings, the figurative meaning is of paramount importance. When it comes to figurative meanings, a number of approaches are deployed to express the meanings of idioms such as metaphor, metonymy, rhetoric, comparison (simile), and exaggeration For example, with the idiom "bắt cá hai tay", people can understand it literally: each hand tries to catch a fish, and as a result, they cannot catch any fish. However, Vietnamese people have commonly put this idiom into a broader context to refer to people with "double" thoughts desiring to have/ do many things at the same time (Hoàng Văn Hành, 2004). Along with the content of wisdom, shades of appreciation and attitudes are usually integrated into each idiom such as respect, approval, disagreement, disregard, sympathy, just a few to name. For example, the idiom "nói thánh nói tuoóng" not only expresses the concept of "brag/ boast" but also the attitude of disapproval and depreciation, etc.

\subsubsection{Vietnamese idioms containing} human-body parts

As a constituent part of Vietnamese idioms, Vietnamese idioms containing human-body parts have all syntactic features of idioms in general, but with regard to meaning, Nguyễn Thị Phương (2009) points out that according to Vietnamese folk concept, human-bodypart idioms can be classified based on the scope of symbolization as follows: (a) Scope of appearance is commonly associated with organs and body parts such as "minh" (body), "da" (skin), "tóc" (hair), "mặt" (face) such 
as "tóc bạc da mồi" (to show signs of old age) and "mặt búng ra sũa" (to look very young); (b) Scope of wisdom is commonly associated with organs like "lòng"/"tâm" (heart), "ruôtt" (gut) and "bung"/"da" (stomach), for example "khẩu xà tâm phật" (to have an evil tongue but a kind-hearted mind) and "ruột để ngoài da" (to be care-free); (c) Scope of emotion: This arena is commonly associated with digestive organs such as "lòng" (heart), "ruọt" (gut), "da" (stomach) and "gan" (liver). Idioms containing them may denote positive emotions such as happiness and satisfaction like "mát lòng mát dạ" and "nở tùng khúc ruột" (to be very satisfied) or negative emotions such as sadness, anger and hatred as in "ruột đau nhu cắt" and "bầm gan tím ruột" (to be extremely disappointed); (d) Scope of will is often associated with “lòng” (heart), "gan” (liver), "tâm" (mind), "lung" (back), and "vai" (shoulder). These organs can symbolize both strong will-power as in "bền gan vĩng chi" (to be resolute and persisten), and weak will-power in "nản lòng nhụt chi" (to be discouraged).

From the perspective of culture, humanbody-part idioms also manifest Vietnamese cultural uniqueness more vividly than any other linguistic units (Nguyễn Đình Hiền, 2018). Vietnam is basically an agricultural country, so images used in Vietnamese are closely connected with agricultural activities that are carried out manually such as "chân lấm tay bùn” (arduous manual work), "bán

\section{Source language (SL) emphasis}

Word-for-word translation

Literal translation

Faithful translation

Semantic translation

Regarding SLemphasis, for word-for-word translation and literal translation, the lexical words in source language of both methods are translated singly and out of context. However, the main dissimilarity between them is that mặt cho đất bán lung cho trời" (to work outside in all weather conditions), " $\boldsymbol{d a}$ đá gan vàng” (to have iron constitution), "chung lưng đấu cật", (to have an iron will as a community). In addition, Vietnamese idioms containing body parts vividly reflect the country's customs, norms and lifestyles, namely long-established and honorable traditions as in "uống máu ăn thề", (to vow to be brothers), "chôn rau cắt rốn" (birthplace), social phenomena as in "một cổ hai tròng" (to have two burdens at the same time), "đeo mo vào mặt" (to be ashamed), "bắt cá hai tay" (to make use of), or family relationship in "đầu bac răng long" (to live together till death), "khác máu tanh lòng" (to be from diferrent origins. All of them have made a great contribution to depicting a genuine but lively picture of the community and the natives.

\subsection{Translation theory}

\subsubsection{Translation methods}

In his book "A Textbook of Translation", Newmark defines translation as "a craft consisting in the attempt to replace a written message and/or a statement in one language by the same message and/or statement in another language" (1988: 7). According to him, the central problem of translating has always been whether to translate "literally or freely", so Newmark suggests different translation methods as follows:

\section{Target language (TL) emphasis}

Adaptation

Free translation

Idiomatic translation

Communicative translation

in word-for-word translation, all words are converted singly by their original syntactic structures of the SL while in literal translation, SL grammatical constructions are translated into their closest counterparts in the TL. The 
distinction between "faithful" and "semantic" translation is that the former is inflexible and dogmatic, while the latter is more flexible, admits the creative exemption to full fidelity and accepts the translator's intuitive empathy with the original.

Regarding TL emphasis, adaptation is the "freest" way of translation. It is deployed largely for literary texts in which the themes, characters and plots are frequently preserved; the SL culture is converted to the TL culture. On the same translation-method category, free translation replicates the content without the form of the SL or it is a paraphrase much longer than the SL, which is often wordy and pretentious. Communicative translation, being is fairly straight and conventional, aims to render the precise contextual meaning of the Source Text (ST) in such a way that both content and language are satisfactory and understandable to the readership. A semantic translation, on the other hand, inclines to be more complex, more detailed, more STfocused, and chases the thought-processes rather than the speaker's intent.

\subsubsection{Translation equivalence}

Translation equivalence is one of the core matters of the translation process. It is a term used to denote the perfect relationship that a reader would expect between the ST and Target Text (TT). Nida and Taber (1969) separate two types of equivalence: formal equivalence and dynamic equivalence. While dynamic equivalence is focused on the equivalent effect, formal equivalence is aimed at the message itself. They state that "formal correspondence distorts the grammatical and stylistic patterns of the receptor language, and hence distorts the message, so as to cause the receptor to misunderstand or to labor unduly hard" (1969: 201). Despite the detailed study of both types of equivalence, Nida and Taber then give preference to the dynamic equivalence, because it gives more chances for the translators to modify the form of words so as to achieve the same force of meaning, which proves to be more useful during the translation procedure.

Stepping away from Nida and Taber's ideas of recipient-oriented translation and changes the vision of equivalence in translation, Newmark develops ideas that translation is "rendering the meaning of a text into another language in the way that the author intended the text" (1988: 5). He considers "equivalence effect" an essential intuitive principle, but he also emphasizes that it is the desirable result, rather than the aim of any translation.

From all the above-mentioned viewpoints, it can be concluded that seeking an equivalent or approximate correspondence for all the variables may seem a challenging and very difficult task in translation.

\section{Translation of idioms}

Because each language has its own way of expressing things, idioms are always language- and culture-specific. An idiom in one language may not exist in some other language, or that language may have a very different idiom to convey the same meaning. This is the reason why the translation of idioms at times proves to be rather strenuous and problematic.

First of all, the translator needs to identify idioms in a given text. This is of principal importance, because meanings of idioms should never be understood literally. Then the translator must also be able to "use idioms fluently and competently in the TL" (Larson, 1984: 116). Larson claims the significance of the ability to use TLidioms naturally because that ensures that the translator's production of smooth and lively 
TL text as well as preservation of the ST stylistic features. The final difficulty is finding a TL expression with the same meaning in spite of the fact that, very often, an idiomatic expression in one language does not always have equivalence in another language.

Newmark highlights that idioms should "never be translated word-for-word" (1988: 125) and Ingo states that "translating an idiom literally is rarely successful, and should therefore be avoided at all costs" (1990: 246).

A number of English learners (Amir, 2012; Gabriella, 2016; Sanna, 2010) have done research into the translation of idiom and applied the theories on idiom translation to practicing translating idioms in literary works. Generally, they have discussed translation loss, especially during the translation of idioms because, according to them there is an unavoidable loss of meaning when the text includes expressions which are unique and peculiar to the SL culture. Holding the same view, Nida and Taber (1969) emphasize that idioms generally suffer a variety of semantic adjustments in translation, as an idiom in one language rarely has the same meaning and function in another language. The translator should, therefore, make every attempt to find an equivalent TL idiom for a SL idiom; otherwise, the idiom should be translated with a "normal", non-idiomatic expression which carries the similar meaning.

With respect to body part idioms, plenty of theses and dissertations have been done so far, some of which are "Comparative Analysis of English and French body idioms" by Martina (2013); "Chinese translation of English human body idioms based on the fuctional equivalence theory” by Fang (2013). Besides presenting theories related to human-body-part idioms, these studies primarily clarify similarities and differences between English body idioms and those of other languages (French and Chinese) and suggest some ways to find equivalent idioms containing body parts.

In Vietnam, although several studies on human-body-part idioms have been implemented such as those of Nguyễn Thị Phương (2009), Nguyễn Thị Bích Liên (2012), and Nguyễn Trung Kiên (2013), they are restricted to listing, comparing and contrasting English human-body-part idioms with Vietnamese ones; and finding Vietnamese equivalence of English humanbody-part idioms as well as translating them into Vietnamese, especially when comparing two English novels and their Vietnamese translation versions, have not been paid much attention to. This is a gap which this study would try to fulfill.

\section{Methodological framework}

\subsection{Research materials}

With a view to implementing the study as objectively as possible, a pilot study was deployed in the first step. A variety of materials such as bilingual magazines, novels, short stories and dictionaries were used as reference sources; and English and Vietnamese idioms containing human-body parts from these sources were carefully collected and counted. In the current study, somaticidioms were collected from two classic novels: "The Godfather" (TGF) (1969) and “To Kill a Mockingbird” (TKAMB) (2015). In Vietnam, their translated versions " $B o ̂ ́$ già” (BG) (2017) by Ngọc Thứ Lang and "Giết con chim nhại" (GCCN) (2017) by Huỳnh Kim Oanh and Phạm Viêm Phương respectively are appreciated by linguists and have become familiar to readers, so they would be used as contrastive versions of the two original novels. Besides, several other 
sources were also used as reference sources such as bilingual magazines, novels, short stories, dictionaries, and some articles on the Internet.

\subsection{Research methods}

The current paper chooses triagulation as a guideline to achieve the research aims, particularly, the triangulation of qualitative, quantitative and comparative research methods are mainly used. While qualitative methods provides the current researcher with in-depth and rich data, quantitative methods presents numourous quantity of data embedding with statistic features for preliminary interpretation. The study also took a largely qualitative research, which is complemented by descriptive analysis which dealt with the contents of the selected novels and their Vietnamese versions. The quantitative analysis quantified the frequency of the deployment of human-bodypart idioms from the data sources. Then, based on the statistical findings in each data source, the study was generally designed as a comparative investigation. According to Gast's comparative approach (2011), both English and Vietnamese idioms were broken down into their lexical and semantic components then compared and contrasted. Comparative processes were conducted when English was considered as the base language and Vietnamese as the compared language. The current study also refered to Tran Thi Ngan's (2017) evaluation of the translation of a film as the guideline when processing the selected data. The final goal of these mixed methods is to categorize the similarities and differences between English and Vietnamese idioms containing human-body parts in terms of their syntactic and semantic features.

\subsection{Data collection and analysis}

Based on the aforementioned methodology, this study was conducted under the following procedures: after English idioms containing human-body parts and their Vietnamese translations were carefully collected from the research materials, the features of these idioms were discussed with a view to seeing how frequently they appeared in the selected literary works as well as identifying the similarities and differences between English somatic idioms and their Vietnamese versions. Then, Lâm Quang Đông's suggested translation steps (2015: 8-9) were deployed as a guideline for synthesizing and evaluating the ways translators practice translating these types of idioms. To make it brief and succinct for readers to follow, some charts and tables were presented, in which statistics of body parts appearing in idioms were calculated and edited in the form of figures and percentages. Also in this step, the study provided some explanations on the English idioms that can be then substituted by a Vienamese nonidiomatic counterpart with the information not covered by the English idioms, namely periphrasis (paraphrases) or calque (borrowed words).

\section{Findings and discussions}

5.1. The frequency of English idioms containing human-body parts in TGF and TKAMB and their Vienamese equivalents in $B G$ and $G C C N$ 


\begin{tabular}{|c|c|c|c|c|}
\hline Order & Body parts & $\begin{array}{c}\text { Vietnamese } \\
\text { meanings }\end{array}$ & $\begin{array}{c}\text { Number of idioms } \\
\text { containing body } \\
\text { parts }\end{array}$ & $\begin{array}{c}\text { Percentage } \\
(\%)\end{array}$ \\
\hline 1 & Eye & Mắt & 14 & 13.21 \\
\hline 2 & Hand & Tay & 12 & 11.33 \\
\hline 3 & Head & Đầu & 10 & 9.43 \\
\hline 4 & Heart & Tim, tâm & 8 & 7.54 \\
\hline 5 & Foot/feet & Chân & 8 & 7.54 \\
\hline 6 & Face & Mặt & 7 & 6.61 \\
\hline 7 & Blood & Máu & 5 & 4.73 \\
\hline 8 & Arm & Cánh tay & 4 & 3.78 \\
\hline 9 & Nose & Mũi & 4 & 3.78 \\
\hline 10 & Heel & Gót chân & 3 & 2.83 \\
\hline 11 & Shoulder & Vai & 3 & 2.83 \\
\hline 12 & Nerve & Dây thần kinh & 3 & 2.83 \\
\hline 13 & Bone & Xương & 2 & 1.89 \\
\hline 14 & Brain & Não & 2 & 1.89 \\
\hline 15 & Ear & Tai & 2 & 1.89 \\
\hline 16 & Gut & Ruột & 2 & 1.89 \\
\hline 17 & Finger & Ngón tay & 2 & 1.89 \\
\hline 18 & Tooth/teeth & Răng & 2 & 1.89 \\
\hline 19 & $\begin{array}{c}\text { Mind/ Eyebrow/ Cheek/ } \\
\text { Tongue/ Neck/ Throat/ } \\
\text { Limb/ Belly/ Stomach/ } \\
\text { Knee/ Flesh/ Muscle/ } \\
\text { Skin }\end{array}$ & $\begin{array}{c}\text { Tâm/ Lông mày/ Má/ } \\
\text { Lưỡi/ Cồ/ Họng/ Chi/ } \\
\text { Bụng/ Dậ dày/ Đầu } \\
\text { gối/ Thịt/ Cơ/ Da }\end{array}$ & 1 each & 0.94/ each \\
\hline Total & 31 & 31 & 106 & 100 \\
\hline
\end{tabular}

Table 5.1: English idioms containing human-body parts in TGF and TKAMB and their Vienamese equivalents in BG and GCCN

Table 5.1 above illustrates the number and percentage of English human-body-part and somatic idioms used in the two original novels. It should be borne in mind that some idioms containing two identical body parts such as "arm in arm" and "head to head" were only counted as one idiom; for idioms containing two interdependent body parts such as "eyes pop out of head", the main body parts would represent the whole idiom; with idioms containing two independent body parts like "from head to foot" and "fight foot and nail", the first body part would represent the whole idiom; idioms appearing more than once would be counted as one idiom. Looking at Table 5.1, it is noticeable that in two novels alone, a variety of human-body parts are referred to (31 body parts); there are a large number of English human-body-part idioms with a total of 106 ones. In TGF, there are 70 idioms while in TKAMB, 36 different idioms are mentioned. However, not all body parts are utilized equally.

In terms of frequency, all body parts mentioned can be divided into four groups. The first group includes body parts that are most frequently used in humans' daily activities like "eye", "hand" and "head". 
They account for more than a third of the total number of idioms (34\%). "Foot", "heart", "face", "blood", "arm" and "nose" constitute the second group with body parts appearing relatively frequently in two novels $(26 \%)$. The third group consists of body parts which appear in low frequency, including "bone", "gut”, "finger", "tooth/ teeth", "ear", "brain", "nerve”, "heel" and "shoulder" (20\%). Some of them are internal organs such as "bone", "gut", "brain" and "nerve" while some are external parts that are less frequently used, namely "finger", "ear", "heel" and "shoulder". The last one includes idioms with the lowest frequency of appearance, most of which are composed of internal organs such as "muscle", "flesh", "stomach", "belly", "tongue", and "mind" $(12 \%)$.

The majority of idioms in two novels contain one body part (97 idioms), e.g. "lose one's head", "hate one's guts", "hit the nail on the head", to name a few. There are nine idioms containing more than one somatic component, among which there are five idioms containing two identical body parts, namely "head to head", "arm in arm", "to grin from ear to ear", "to tear someone limb from limb" and "an eye for an eye".

5.2. The meaning of English idioms containing human-body parts in TGF and TKAMB and their Vienamese equivalents in $B G$ and $G C C N$

5.2.1 The meaning of English idioms containing human-body parts in TGF and TKAMB

When integrated into idioms, body parts are rarely understood literally, but figuratively instead. The two most frequently deployed methods of using somatic idioms in TGF and TKAMB are metaphor and metonymy.
Regarding such figures of speech, body parts often represent:

- Cognition and wisdom: Some body parts of this group can be "head", "mind", "brain", "nerve", "mind", "heart" and "eye". "Head" and "brain" account for a considerable number of idioms within this scope of meaning. They symbolize the spirit and rational intellect with both positive meaning such as "have brains" (to have reason), "keep one's head" (to stay calm); and negative meaning as "knock heads" (to argue), "lose one's head" (to lose control). Additionally, some other body parts also represent intellect awareness and mindfulness, namely "eye" in "have an eye on something" (to remain alert and watchful for someone or something), "nose" in "have a nose for something" (to have an intuitive ability to detect or excel at something), "mind" in "keep your mind on something" (to keep paying attention to something), "ear" in "in a pig's ear" (nonsense).

- Feelings and emotions: When it comes to feelings and emotions, "heart" is usually the first thing to cross one's mind. "Heart" is considered the center of human feelings and the symbol of passions and affections of the human souls, ranging from sincerity as in "from the bottom of one's heart" (in a very sincere and deeply felt way) to painfulness in "break one's heart" (to overwhelm someone with sadness). Apart from that, people often use internal organs like "gut", "blood", "bone", "nerve"... when referring to negative feelings such as "hate one's guts" (to hate someone very much), "make one's blood boil" (to be very angry), "in cold blood" (in a cruel way), "bone-shaking” (violently). Besides, a small number of idioms of this group contain body parts such as "eye" in "knock one's eyes out" (to astonish and delight someone), 
"eyebrow" in "raise one's eyebrows" (to be surprised), "nose” in "turn up one's nose at something" (to look down on something), "cheek" in "turn the other cheek" (to ignore someone/something), "teeth" in "set one's teeth on edge" (to upset someone), "face" in "make a face" (to produce an expression on one's face), and "head" in "shake one's head" (to refuse).

- Will-power: The literal meanings of some organs are transferred metaphorically to express human will such as "nerve" in "have the nerve to do something" (to have courage), "gut" in "to have guts" (to have courage), "head" in "hold up one's head" (to be proud), "face" in "face up to" (to confront), "foot" in "fight tooth and nail" (to fight hard) and "skin" in "grow a thick skin" (to be able to ignore others' criticisms).

- Behaviors and manners towards others: They can be willingness to help such as "give/ lend someone a hand" (to help someone), kindness as in "warm-hearted" (to be kind and loving), unfriendliness as in "keep/ hold someone at arm's length" (to distance from someone), seriousness as in "keep a straight face" (to try not to laugh), irritation as in "set one's teeth on edge" (to upset someone)), disregard as in "raise one's eyebrows" (to be surprised), deception as in "lead someone by the nose" (to lead someone by coercion).

5.2.2. The Vietnamese equivalence of English idioms containing human-body parts in $B G$ and $G C C N$

After English human-body-part idioms in two classic novels "The Godfather" and "To Kill a Mockingbird" and their Vietnamese versions are compared and contrasted, it is remarkable that there are four groups of Vietnamese translated equivalents of English human-body-part idioms as follows:
Absolute equivalence: The first group includes English human-body-part idioms translated into Vietnamese idioms with the same meanings while the body parts kept unchanged. These English somatic elements have their virtually absolute equivalence in Vietnamese. This way of translation appears in a very small number in two translated versions. For example:

His mouth was slightly open, and he looked at Jem from head to foot. (TKAMB: 555)

$\rightarrow$ Miệng ông ta hé mở, và ông ta nhìn Jem từ đầu đến chân. (GCCN: 573)

It is noticeable that the Vietnamese idiom "tù đầu đến chân" is an absolute equivalent of "from head to foot" in terms of semantics, lexicology and structure. All elements in the SL idiom are retained, even the word order, i.e. two somatic nouns "head" and "foot" are translated into "đầu" and "chân" respectively; two prepositions "from" and "to" are translated into "tù" and "đến" respectively. Another outstanding point is that "head" and "foot" are not figuratively expressed, i.e. "đầu" and "chân" are simply understood as two familiar body parts.

This translation strategy might seem to be very ideal in nature; nevertheless, such ideal matches in more sophisticated somatic idioms can rarely be achieved because other aspects, such as register, style, or rhetorical effect, must be considered as well.

Here are some more examples of this kind of absolute equivalence: 


\begin{tabular}{|c|c|c|c|}
\hline Body parts & $\begin{array}{l}\text { English } \\
\text { idioms }\end{array}$ & Meaning & Vietnamese equivalents \\
\hline Head & $\begin{array}{c}\text { Shake } \\
\text { one's head }\end{array}$ & To refuse & $\begin{array}{l}\text { Don Corleone shook his head. "I trust these two men } \\
\text { with my life. They are my two right arms." (TGF: 20) } \\
\rightarrow \text { Ông Trùm lắc đầu: "Không được. Hai thằng này không } \\
\text { những là phụ tá mà còn là con cháu trong nhà" (BG: 16) }\end{array}$ \\
\hline Face & $\begin{array}{c}\text { Show } \\
\text { one's face }\end{array}$ & $\begin{array}{l}\text { To make an } \\
\text { appearance }\end{array}$ & $\begin{array}{l}\text { However, rest assured that if the young man shows his } \\
\text { face here I shall immediately report his presence to the } \\
\text { authorities (TGF: 199) } \\
\rightarrow \text { Tuy nhiên xin các ông cứ yên tâm nếu anh chàng các } \\
\text { ông đang tìm có ló mặt ra thì tôi sẽ lập tức báo ngay cho } \\
\text { nhà chức trách (BG: 196) }\end{array}$ \\
\hline Eyes & $\begin{array}{l}\text { Keep one's } \\
\text { eyes open }\end{array}$ & $\begin{array}{l}\text { To remain alert } \\
\text { and watchful } \\
\text { for someone or } \\
\text { something }\end{array}$ & $\begin{array}{l}\text { The most humble of men, if he keeps his eyes open, can } \\
\text { take his revenge on the most powerful (TGF: 9) } \\
\rightarrow \text { Còn mở mắt ra được thì còn có ngày một thằng hèn } \\
\text { yếu nhất có quyền rửa hận một tay thế lực nhất (BG: } 8 \text { ) }\end{array}$ \\
\hline Eyebrow & $\begin{array}{c}\text { Raise one's } \\
\text { eyebrows }\end{array}$ & $\begin{array}{l}\text { To elicit } \\
\text { surprise } \\
\text { or offense } \\
\end{array}$ & $\begin{array}{l}\text { Uncle Jack raised his eyebrows and said nothing } \\
\text { (TKAMB: 154) } \\
\rightarrow \text { Chú Jack nhướn mày và chẳng nói gì (GCCN: 159) }\end{array}$ \\
\hline
\end{tabular}

\section{Partial equivalence with same meanings} but the elements of body parts removed/ changed: The second group includes English human-body-part idioms converted into Vietnamese idioms with the same meanings but the body parts are removed, replaced or combined with new ones. With respect to the first sub-group of English human-body-part idioms translated into Vietnamese idioms with the same meanings and the body parts totally removed, take the following version as an example:

Her mother too had always been a little disinterested in her, holding her at arm's length. (TGF: 200)

$\rightarrow$ Cũng như chồng, ít khi bà gần gũi con gái, đối xử với cô theo kiểu kính nhi viễn chi. (BG: 192)

There is a likelihood that when people have an intimate relationship, they will get in touch so close to each other's bodies. Hence, "at arm's length" indicates a certain distance in communication and interaction between two people. However, the body part "arm" in the English idiom is removed totally in the
Vietnamese idiom and replaced by an idiom originated from a Confucius's saying: "Vu dân chi nghĩa, kính quỷ thần nhi viến chi, khả vị tri hĩ", which means "to do the people good, although you show respect for ghosts/ spirits (respectable and superior people), do not flatter them, but should stay away from them, that is considered sensible" (Hy Vọng \& Lê Trai, 2016). In "kính nhi viễn chi", there are some Sino-Vietnamese elements: "kinh" means "to respect" and "viễn" means "to stay away from". Nowadays, in Vietnamese, the overall meaning is either "to show respect to someone to their face but in reality keep away from him/her" or "to keep away from someone in an ironic and sarcastic way". In this situation, it is understood with the latter meaning (the mother-in-law treats her daughter-in-law with indifference and neglect). It can be said that while cultures using English language tend to view things from physical perspective, Oriental cultures, including Vietnamese one, pay more attention to cultural factors that are influenced by old traditions and norms. 
The prime example for translating English human-body-part idioms into Vietnamese ones with the body parts replaced by a new one is the sentence:

"This speech of the Detroit Don was received with loud murmurs of approval. He had hit the nail on the head" (TGF: 247).

$\rightarrow$ "Mọi người ồn ào đồng tình với bài phát biểu của ông trùm Đơtroit. Hắn đã nói đúng tim đen” (BG: 238).

In this example, "Head" is translated into "tim" (heart) and "hit the nail" into "nói đúng" (to say something exactly). Once again, like the example mentioned above, this English idiom borrows the practically visual image of "hitting a nail on the head" to describe an action requiring high precision, whereas Vietnamese expressive style emphasizes the metaphoric symbolism, in which the Vietnamese view "tim" (heart) as the place of hidden thinkings, intentions and emotions (tim den). This version seems to be appropriate as it conveys the intended meaning but still sounds natural to readers in terms of culture at the same time.

However, a more popular way to translate somatic idioms of this group is to find partly equivalent Vietnamese somatic idioms in which another body part is added. In this way, the meanings of idioms are retained while the degree of vividness in describing persons, things and situations is significantly enhanced. One example is the following version:

Chao ôi, khi thần tượng xuất hiện bằng xương bằng thịt thì còn gì thê thảm cho bằng. (BG: 148)

$\rightarrow$ But seeing them now in the flesh I was like seeing them in some horrible makeup. (TGF: 159)

When people in English speaking nations want to express the idea "see someone physically", they use "see someone in the flesh". The Vietnamese also use the image "flesh" (thit) to express the same idea, but they combine it with a very close image to "flesh" - "xuong" (bone) - to make up the idiom "bằng xương bằng thịt". A remarkable point is that this Vietnamese idiom is a symmetric one, with a symmetry between "xuoong" and "thịt". That the word "bằng" is repeated twice creates a rhythmic effect for the whole expression, so it sounds very Vietnamese when this sentence is read out loud. A similar case is that the SL idiom "racked their brains for" (TGF: 256) is translated into "điên đầu vắt óc" (BG: 247). In this case, the word "đầu" (head) is added to "óc" (brain), "rack" is transferred into two elements "điên" and "vắt", thus making up a symmetry idiom "điên đầu vắt óc" (điên corresponds to vắt while đầu corresponds to $o ́ c$ ). Generally speaking, notwithstanding an addition of a new somatic component, this translated version sounds satisfactory because not only does it convey the original meaning in the SL idiom but also makes sure that the new style and register are suitable to the receptors.

Consider the following examples of the partial equivalence with same meanings but the elements of body parts removed/changed: 


\begin{tabular}{|c|c|c|c|}
\hline Body parts & $\begin{array}{l}\text { English } \\
\text { idioms }\end{array}$ & Meaning & Vietnamese equivalents \\
\hline Ear & $\begin{array}{l}\text { Grin from } \\
\text { ear to ear }\end{array}$ & $\begin{array}{l}\text { To have a broad, } \\
\text { enthusiastic } \\
\text { smile }\end{array}$ & $\begin{array}{l}\text { She grinned from ear to ear and walked toward our father, } \\
\text { but she was too small to navigate the steps (TKAMB: 478) } \\
\rightarrow \text { Nó cười toe toét miệng và đi tới chỗ bố tôi, nhưng } \\
\text { nó quá nhỏ không thể hướng về phía những bậc thềm } \\
\text { (GCCN: 483) }\end{array}$ \\
\hline Throat & $\begin{array}{c}\text { Clear one's } \\
\text { throat }\end{array}$ & $\begin{array}{l}\text { To make a } \\
\text { coughing sound } \\
\text { in order to } \\
\text { attract attention }\end{array}$ & $\begin{array}{l}\text { He seemed uncomfortable; he cleared his throat and } \\
\text { looked away (TKAMB: } 302 \text { ) } \\
\rightarrow \text { Ông ta có vẻ không thoải mái; ông ta hắng giọng và } \\
\text { nhìn chỗ khác (GCCN: p.307) }\end{array}$ \\
\hline Shoulder & $\begin{array}{l}\text { Take that } \\
\text { load off } \\
\text { one's } \\
\text { shoulders }\end{array}$ & $\begin{array}{l}\text { Relieve } \\
\text { someone of } \\
\text { some of his/her } \\
\text { load }\end{array}$ & $\begin{array}{c}\text { What if that, finally, was too much for him, and he made } \\
\text { Michael his successor, knowing that Michael would take that } \\
\text { load off his shoulders, would take that guilt?” (TGF: 380) } \\
\rightarrow \text { Nếu cụ đã đuối hơi rồi và cho Maicơn nối nghiệp vì } \\
\text { biết nó sẽ gỡ gánh nặng này cho cụ, chịu tội thay cho cụ, } \\
\text { thì sao? (BG: } 378 \text { ) }\end{array}$ \\
\hline
\end{tabular}

Partial equivalence with literal meanings of body parts: The third group includes English somatic idioms translated into Vietnamese phrases/set expressions literally with the same meanings. This way of idiomatic translation can be called "translation by paraphrase". The translated versions can be divided into two sub-groups: literal paraphrase and figurative paraphrase.

With respect to literal paraphrase, there can be named a huge number of examples because when an equivalent idiom to the SL idiom cannot be found or when it is necessary to simplify an idea, this is one easy way to translate English idioms. Take the following sentence as an example:

"The main one is, if I didn't I couldn't hold up my head in town, I couldn't represent this county in the legislature" (TKAMB: 148)

$\rightarrow$ "Lý do chính là, nếu bố không làm được bố không thể ngẩng cao đầu trong thị trấn này được, bố không thể đại diện hạt này trong cơ quan lập pháp" (GCCN: 154)

The Vietnamese version employs the faithful translation method, in which the translated idiom reproduces the accurate contextual meaning of the source idiom and still retains its grammatical structure, lexical elements and word order. To be more specific, "hold up" is faithfully translated into "ngẩng cao" and "head" into "đầu", "ngẩng cao đầu" in Vietnamese has the same meaning with that in English, which is "to behave proudly; to maintain one's dignity". Consequently, the Vietnamese idiom is completely faithful to the intention and the text-realization of the original texts.

On the other hand, figurative paraphrase does not rephrase the English idioms literally or word-by-word, but aims to find the hidden messages and then re-express them by using metaphorical words/phrases. For instance, the word "brains" in the sentence "Fontane had some brains after all" (TGF: 147) is translated into "đầu óc", becoming "Thì ra Giôuni (Phôntêin) cũng là đứa có đầu óc" (BG: 138). "Brain" in both cultures stands for intelligence, reason and wisdom. While the American writer says it directly and literally, the two Vietnamese translators add one more stage of transferring the writer's intended meaning into metaphorical meaning, thereby re-expressing it in Vietnamese properly. This is far more readable and understandable than 
the translated version "có não", which sounds very unnatural and strange to Vietnamese readers. Below are the examples of this kind of equivalence:

\begin{tabular}{cccl}
\hline Body parts & $\begin{array}{c}\text { English } \\
\text { idioms }\end{array}$ & Meaning & \multicolumn{1}{c}{ Vietnamese equivalents } \\
\hline Shoulder & $\begin{array}{c}\text { Have/get a } \\
\text { good head } \\
\text { on one's } \\
\text { shoulders }\end{array}$ & $\begin{array}{c}\text { To be } \\
\text { sensible } \\
\text { and intelligent }\end{array}$ & $\begin{array}{l}\text { Mister Jem, I thought you was getting' some kinda head } \\
\text { on your shoulders (TKAMB: 414) } \\
\rightarrow \text { Cậu Jem, tôi nghĩ cậu có cái đầu biết suy nghĩ trên vai } \\
\text { cậu chứ (GCCN: 419) }\end{array}$ \\
\hline Hand & $\begin{array}{c}\text { Throw up } \\
\text { one's hands }\end{array}$ & $\begin{array}{c}\text { To submit or } \\
\text { give up }\end{array}$ & $\begin{array}{l}\text { At the end of the eight hours Don Corleone had thrown up } \\
\text { his hands in a helpless gesture (TGF: 44) } \\
\rightarrow \text { Bố Già mới chán nản đưa hai tay lên than van với } \\
\text { đông đủ cử toạ (BG: 42) }\end{array}$ \\
\hline Heart & $\begin{array}{c}\text { At the heart } \\
\text { of someone }\end{array}$ & $\begin{array}{c}\text { The most } \\
\text { important part } \\
\text { of something }\end{array}$ & $\begin{array}{l}\text { But he decided to strike right at the heart of the enemy } \\
\text { (TGF: 217) } \\
\rightarrow \text { Nhưng đã đánh là phải đánh trúng tim địch thủ (BG: } \\
215)\end{array}$ \\
\hline
\end{tabular}

Non-equivalence: The last group contains translated versions in which English humanbody-part idioms do not have equivalence in Vietnamese; consequently, translation loss is unavoidable even if translators make great efforts to translate them. For example, the idiom "stick my neck out" (to risk incurring criticism or anger by acting or speaking boldly) is removed as can be seen in the translated version as in the example:

"I'm a lawyer. Would I stick my neck out? Have I uttered one threatening word?" (TGF: 45)

$\rightarrow$ Xin đừng quên nghề tôi là luật sư! Một con nhà luật mà...áp lực? Mà lại buông lời hăm dọa ai sao? (BG: 40)

The explanation for this can be that the author intends to focus on the sentence coming afterwards "Have I uttered one threatening word?", so there is no need to translate the sentence mentioned above. However, in other cases, although the English human-body-part idioms are not translated into the Vietnamese versions, the translators use "compensation" phrases so that their meanings are preserved. For instance, Mario Puzo wrote that:

I was in love with him for three years. I used to come down to New York whenever he sang at the Capitol and scream my head off. (TGF: 30 )

The idiom "to scream one's head off" means "to scream out to one's full capacity", so in general, this idiom can be used to describe someone's excitement, enthusiasm or even fear. Yet, Ngọc Thứ Lang, with his marvelous taste in literature, omitted that idiom and expressed it as:

Anh biết không, em mê Johnny từ 3 năm nay lận! Có Johnny trình diễn ở Capitol thì thế nào cũng phải đi nghe. (BG: 28)

It is noticeable that the English idiom "scream one's head off" is not eliminated totally, because it is replaced by "thế nào cũng phải đi nghe" in the Vietnamese version. The idea of "to scream very loudly when one is scared or excited" is removed but the literary effects are intensified and create the aftertaste for readers. Instead of translating the idiom into "Anh biết không, em mê Johnny tù 3 năm nay lận! Có Johnny trình diễn ở Capitol thi lần nào em cũng hét hò ầm ĩ cả" (the reserachers' translated version), the translator expresses the opposite, i.e. despite difficulties or being busy, the character still arranges to 
go for Johnny's show. The suggested version "hét hò ầm $\tilde{\imath} c a ̂ "$ is not a bad idea, as it uses the faithful translation method, but the shade of expression is rather limited and its artistic effect is not as much as that of "thế nào cũng phải đi nghe", which means "I have to go and see him whatever happens". The outstanding point of this sentence lies in the phrases "thế nào cũng phải" (whatever happens) that underlines the character's enthusiasm and eagerness for the singer's performance.

Below are the examples of this kind of no equivalence:

\begin{tabular}{|c|c|c|c|}
\hline Body parts & $\begin{array}{l}\text { English } \\
\text { idioms }\end{array}$ & Meaning & Vietnamese equivalents \\
\hline Blood & Bad blood & $\begin{array}{c}\text { Tension } \\
\text { and disdain } \\
\text { due to past } \\
\text { disagreement/ } \\
\text { transgressions }\end{array}$ & $\begin{array}{l}\text { It gets rid of the bad blood (TGF: 121) } \\
\rightarrow(\text { No equivalence) }\end{array}$ \\
\hline Bone & $\begin{array}{l}\text { Make } \\
\text { one's bone }\end{array}$ & $\begin{array}{l}\text { To solidify } \\
\text { one's reputation } \\
\text { (usually in } \\
\text { a criminal } \\
\text { organization) }\end{array}$ & $\begin{array}{l}\text { And then after he had "made his bones" he had received a } \\
\text { good living from the Family, a percentage of an East Side } \\
\text { "book" and a union payroll slot (TGF: 82) } \\
\rightarrow \text { Sau khi lập đầu danh trạng, gã được trả lương rất khá, } \\
\text { ăn phần trăm của đám bao thâ̂u đánh cá bên East Side và } \\
\text { được ăn chia với các nghiệp đoàn (BG: } 80 \text { ) }\end{array}$ \\
\hline Eye & Bat an eye & $\begin{array}{l}\text { To cease looking } \\
\text { at someone or } \\
\text { something. }\end{array}$ & $\begin{array}{l}\text { Miss Stephanie said Atticus didn’t bat an eye (TKAMB: } \\
\text { 434) } \\
\rightarrow \text { Cô Stephanie nói bố Atticus thản nhiên như không } \\
\text { (GCCN: 439) }\end{array}$ \\
\hline
\end{tabular}

\section{Implications}

Based on the research results, several strategies for learning and translating English idioms containing human-body parts into Vietnamese are suggested below:

The first strategy involves using an idiom of similar meaning and form, which means using an idiom in the target language with approximately the same meaning as the source language idiom and that idiom contains equivalent lexical items. In this sense, equivalent lexical items mean that body parts in the source language are retained and translated into equivalent body parts of the target language, and other components have their own equivalence in the target language. For example, "hand in hand" can be translated into "tay trong tay". In some other cases, body parts are kept unchanged but several elements are added to the English components or transformed, which can been seen in "with all one's heart" $\rightarrow$ "thành tâm thành $y$ " when "thành $y$ " is added.

Using an idiom of similar meaning but dissimilar form is the second strategy which is based on the possibility of finding an idiom in the target language with a similar meaning to that of the source language idiom or set expression, but containing different lexical items. In other words, either sourse language somatic elements are removed totally, replaced by, or combined with new body parts. Here are some examples of this kind: "heart and soul" $\rightarrow$ tràn đầy sinh lưc when "heart" is removed; "lose heart" $\rightarrow$ nản lòng nhut chi where "lòng" (mind) replaces "heart"; or "close one's eyes" $\rightarrow$ nhắm mắt xuôi tay wher "tay" (hand) is added. 
Paraphrasing is the third type of translation strategy drawn from the research. Literal paraphrasing is characterized by the preservation of English human-body parts in Vietnamese idioms and the literal expression of the English idioms as can be seen in "face up to" $\rightarrow$ "sơ phải đối mặt". With the figurative paraphrasing, the translation process is more complicated when the translator has to understand the symbolic meanings of the English idioms and re-express them without the original somatic words such as in "Scout's got to learn to keep her head $\rightarrow$ "(Scout phải hoc cách) giũ bình tĩnh".

Last but not least, omitting is the translation strategy applied mostly in the sentence or paragraph level. The reason for this phenomenon is that when an idiomatic expression is omitted, most of the time, there is a "loss" in terms of meaning. This kind of loss can be either total or compensable. Here is an example: "I'm a lawyer. Would I stick my neck out?" $\rightarrow$ "Xin đù̀ng quên nghề tôi là luật sur! Một con nhà luật mà...áp lục? (Non equivalence).

\section{Conclusion}

The current paper has dealt with two primary issues: describing the syntactic and semantic features of English and Vietnamese idioms containing human-body parts and then working out the similarities and differences between English and Vietnamese idioms containing human-body parts used in two selected English novels "The Godfather" and "To Kill a Mockingbird" and their Vietnamese translated versions "Bố già" and "Giết con chim nhai" respectively. The review of literature provides theoretical background on English and Vietnamese idioms, including human-body-part ones, and the translation theories. Despite the differences in defining, classifying and characterizing them, many researchers and linguists share the same view about idioms that they are well-structured phrases with a high degree of inseparability and an unlikely possibility of deducing the whole meaning of that idiom from their components. The main tools deployed throughout the survey are contrastive analysis and sampling method. After collecting all human-body-part idioms in the two English novels and their Vietnamese versions, the reserachers find out that the English idioms containing humam body parts have different types of Vietnamese equivalents such as absolute equivalent where both the meanings and the elements of human-body parts are kept, or partially equivalent where either the meaning or the elements of human-body parts are maintained. However, the research results also point out that in several cases no Vietnamese equivalents to the English idioms containing human body parts are found in the selected data.

In short, it is expected that readers of this paper will, to some extent, draw out useful experience for themselves to enrich their idiom vocabulary and facilitate their translation competences. As cultural barriers among languages are still in existence, the translators should equip themselves with suitable and effective strategies for translating idioms in general and somatic idioms in particular from English into Vietnamese.

\section{References}

\section{Vietnamese}

Mai Ngọc Chừ, Vũ Đức Nghiệu, Hoàng Trọng Phiến (1997). Co sở ngôn ngũ học và tiếng Việt. Hà Nội: Nxb. Giáo dục.

Nguyễn Thiện Giáp (1996). Tù̀ và nhận diện tù tiếng Việt. Hà Nội: Nxb Giáo dục.

Hoàng Văn Hành (2004). Thành ngũ học tiếng Việt. Hà Nội: Nxb Khoa học Xã hội.

Nguyễn Đình Hiền (2018). Tìm hiểu thành ngữ, tục ngữ tiếng Việt dưới góc nhìn của quy luật vận động và 
phát triển. Tạp chí Nghiên cứu Nước ngoài, 34(1), 91-105.

Nguyễn Xuân Hiếu, Trần Mộng Chu (1960). Khảo luận về Nguyễn Khuyến. Hà Nội: Nxb Nam Sơn.

Nguyễn Trung Kiên (2013), Tìm hiểu thành ngũ tiếng việt chứa tù chi bộ phận co thể người trên li thuyết ba bình diện ngũ pháp, ngũu nghĩa, ngũ dụng, Luận văn thạc sỹ ngôn ngữ học, Đại học sư phạm Hà Nội, Hà Nội.

Nguyễn Thị Phương (2009). Đặc trung ngôn ngũu-văn hóa của các tù chỉ bộ phận co thể người trong thành ngũ tiếng Việt so sánh với tiếng Anh. Luận văn thạc sỹ ngôn ngữ học. Tp. Hồ Chí Minh: Đại học sư phạm Tp. Hồ Chí Minh.

Hoàng Thị Yến (2017). Đặc trưng tín hiệu thẩm mĩ trong thành ngữ so sánh tiếng Việt. Tạp chí Nghiên cưu Nước ngoài, 33(5), 145-155.

Hy Vọng, Lê Trai (2016). Ngày lễ Halloween: Đùa với quỷ thần xung khắc với văn hóa phương Đông. Retrieved on 12/07/2018. https://trithucvn.net/ van-hoa/ngay-le-halloween-quy-than-vanhoa-phuong-dong.html.

\section{English}

Amir, S. (2012). Translation of Idioms and Fixed Expressions: Strategies and difficulties, Department of English, Quchan Branch, Islamic Azad University, Quchan.

Arnold, I. (1986). The English word. Moscow: Vuisshaya Shkola.

Cowie, A. P. (1998). Phraseology: Theory, analysis and applications. Oxford: Oxford University Press.

Lâm Quang Đông (2015). Translation of Vietnamese serial verb constructions (SVCs) and/or multi-verb constructions into English.VNU Journal of Science: Foreign Studies, 31(4), pp. 1-10.

Fang, J. (2013). Chinese translation of English human body idioms based on the fuctional equivalence theory, Jiangshu University, Zhenjiang.

Fowler, H.W., Fowler, F.G, Allen, R.E. (1976). The Concise Oxford Dictionary of Current English. Oxford: Oxford University Press.

Flavell, L., Flavell, R.H. (2000). Dictionary of idioms and their origins. London: Kyle Cathie Ltd.
Gabriella, K. (2016). About the definition, classification, and translation strategies of idioms, Sapientia Hungarian University of Transylvania, Cluj-Napoca.

Gast, V. (2011). Contrastive linguistics: Theories and methods. Thuringia: Friedrich Schiller University.

Ingo, R. (1990). From source language to target language, WSOY, Helsinki.

Koonin, A. (1970). English lexicology. Moscow: State Text-book Publishing House.

Larson, M.L. (1984). Meaning-based translation: A guide to cross- language equivalence. University Press of America: Lanham.

Makkai, A. (1972). Idioms structure in English. The Hague: Mouton.

Martina, N. (2013). Comparative Analysis of English and French Body Idioms, Masaryk University, Brno.

Moon, R. (1998). Fixed Expressions and Texts: A Study of the Distribution and Textual Behaviour of Fixed Expressions in English. Oxford: Clarendon Poress.

Newmark, P. (1988). A Textbook of translation. Prentice Hall: Cambridge.

Nida, E.A., \& Taber C.R. (1969). The theory and practice of translation. E. J. Brill: Leiden.

Tran Thi Ngan (2018). An evaluation of the translation of the film "Rio" based on NewMark's model. VNU Journal of Foreign Studies, 34(2), pp. 62-73.

Sanna, M. (2010). Translating idioms: A case study on Donna Tartt's The Secret History and its Finnish translation, Department of Languages, University of Jyvaskyla, Jyvaskyla.

Stoyanova, I. (2009). Semantic aspects of English body idioms. Diss. IRIM Chisinau, Kishinev.

\section{Data sources}

Ngọc Thứ Lang (2017). Bố già. (Dịch từ tiểu thuyết "The Godfather" của Mario Puzo). Hà Nội: Nxb. Văn học.

Huỳnh Kim Oanh, Phạm Viêm Phương (2017). Giết Con Chim Nhại. (Dịch từ tiểu thuyết "To Kill $a$ Mockingbird" của Harper Lee). Hà Nội: Nxb. Văn học.

Lee, H. (2015). To Kill a Mockingbird. New York: Grand Central Publishing.

Puzo, M. (1969). The Godfather. New York: G. P. Putnam's Sons. 


\title{
THÀNH NGỮ TIẾNG ANH CÓ CHỨA TỬ CHỈ CÁC BỘ PHÂN CO'THỂ VÀ TƯO'NG ĐƯO'NG TRONG TIẾNG VIÊT: NGHIÊN CỨU TRƯỜNG HỢP VỚI HAI TIỂU THUYẾT TIẾNG ANH VÀ BẢN DỊCH TIẾNG VIỆT
}

\author{
Nguyễn Thu Hạnh ${ }^{1}$, Nguyễn Tiến Long ${ }^{2}$ \\ 1. Khoa Tiếng Anh, Học viện Khoa học Quân sụ \\ Kim Chung, Hoài Đức, Hà Nội, Việt Nam \\ 2. Phòng Chính trị, Vùng Hải quân 4, \\ Cam Nghĩa, Cam Ranh, Khánh Hòa, Việt Nam
}

Tóm tắt: Bài báo tập trung nghiên cứu đặc điểm cấu trúc và ngữ nghĩa của thành ngữ nói chung và thành ngữ có chứa từ chỉ các bộ phận cơ thể người nói riêng trong hai tiểu thuyết tiếng Anh The Godfather \& To Kill A Mockingbird và bản dịch tiếng Việt tương đương. Sử dụng phương pháp so sánh và đối chiếu, bài báo chỉ ra thành ngữ tiếng Việt tương đương và không tương đương của thành ngữ tiếng Anh có chứa từ chỉ các bộ phận cơ thể trong các tác phẩm này. Kết quả nghiên cứu sẽ giúp ích nhiều trong dạy và học tiếng Anh, đặc biệt là thành ngữ tiếng Anh, cũng như quá trình dịch thành ngữ tiếng Anh sang tiếng Việt.

Tù khóa: thành ngữ, tương đương, bộ phận cơ thể, dịch Anh-Việt 